Journal of Economics and Behavioral Studies

Vol. 4, No. 5, pp. 268-276, May 2012 (ISSN: 2220-6140)

\title{
The Relationship between Government Size and Economic Growth in Iran; Bivariate and Trivariate Causality Testing
}

\author{
*Salma Keshtkaran¹, Khosrow Piraee², Farzane Bagheri² \\ ${ }^{1}$ Zand Institute of Higher Education-Shiraz, Iran \\ Islamic Azad University (Iran-Shiraz branch), Iran \\ *salma_ke@yahoo.com
}

\begin{abstract}
The aim of this study is to demonstrate the relationship between government size and economic growth in Iran within bivariate and trivariate causality framework. For this purpose, Vector Auto Regressive Model, Johansen Test and Auto Regressive Distributed Lag Model were used for analyzing the long run relationship, whereas Error Correction Model was considered for the short run. Moreover Wald Coefficient was used for bivariate and trivariate causality test. The results show that the relationship between government size and economic growth in Iran is negative. Furthermore there is a one-way causality relationship for the long run and the short run-from government size to economic growth. Inclusion of unemployment and oil revenue (separately) as the third variable causes the relationship to remain negative. However the direction of causality depends on the choice of the third variable. If unemployment rate is considered as the third variable instead, there will be no causality between the two variables in the long run. Although in the short run government size is still the cause of economic growth. However, consideration of oil revenue as the third variable results in a two-way causality relationship between the government size and the economic growth in the long run and the short run.
\end{abstract}

Key words: Government size, Economic growth, Unemployment rate, Oil income

\section{Introduction}

Economic growth has been developing countries apprehension which is the required condition for economic development. Success or failure in achieving required economic growth can cause enhancement or falling the governments and non- developed nation's plans is evaluated based on their national income. It is a fact that no society throughout history has ever obtained a high level of economic affluence without a government. Where governments did not exist, anarchy reigned and little wealth was accumulated by productive economic activity. After governments took hold, the rule of law and the establishment of private property rights often contributed importantly to the economic development of Western civilization, and it has similarly impacted on other societies as well. Government is necessary, though by no means sufficient, condition for prosperity. It is also a fact, however, that where governments have monopolized the allocation of resources and other economic decisions, societies have not been successful in attaining relatively high levels of economic affluence. Economic progress is limited when government is zero percent of the economy, but also when it is at or near 100 percent. The experience of the old Soviet Union is revealing, as was the comparison of East and West Germany during the Cold War era, or that of North and South Korea today. Too much government stifles the spirit of enterprise and lowers the rate of economic growth. One of the most important issues which have been studied in different ways is the impact of government size on long run economic growth. Although the issue has a high level of importance, the empirical ideas about that have had adverse results. There are three overall points of views about the impact of government size on economic growth. According to the first group theory, larger government size is likely to be detrimental to efficiency and economic growth due to some inefficiencies existing in the government's presence and can be an obstacle for development in economy, the second group believe that the government existence is not a hindrance for economic growth, and the third group know the relationship between these two like an inverted $U$, and believe that increasing the government size to a special limit causes increasing the economic growth but results in its decrease by going beyond this limit. 


\section{Literature Review}

Most of the studies related to this subject have been done since 1980's. According to those who oppose the development of government size, increasing the government size causes a decrease in the efficiency of the government expenses. Besides, with the extension of government expenditure, it needs more taxes to support these expenses which results in undesirable allocation of resources. On the other hand, those who agree with increasing the government size believe that extending this size encourages the private investment and results in economic growth. In studies done by Ram (1986), Ghali (1998), Kolluri (2000), Loizides and Vamvoukas (2005), presence of the government in economy is confirmed, and has been shown that increasing the government size results in economic growth. Ram concluded by studying data from 115 countries during 1960-1980 that the effect of rate of total expenses growth of government on the ratio of the real gross domestic product growth is significantly positive. After investigating 10 countries of OECD, Ghali showed that the government size is the reason for economic growth in the countries investigated. Moreover Ghali uses multivariate cointegration techniques, and examines the dynamic interaction between government size and economic growth in a five-variable system, consisting of the growth rate of GDP, total government spending, investment, exports, and imports. Ghali's study shows that government size Granger-causes growth in all countries of the sample. Kolluri using a bivariate framework estimated the long-run relationship between gross domestic product and government spending in the G7 countries for the period 1960-1993. Most of the empirical findings confirm that government spending tends to be income elastic in the long run. This disparate evidence calls for the re-examination of the differences in the causality results. After studying the causality relationship between government size and economic growth in Greece, Ireland and UK, Liozides and Vamvoukas concluded that the government size has been the granger cause for economic growth in short run in all countries and in long run for just Ireland and UK.

They made a trivariate analysis by introducing inflation and unemployment rate (in separate) into the relationship between government size and economic growth and showed that the economic growth has been the granger cause of increasing in the relative size of government in Greece, and, when inflation was included, in the UK. On the other hand, Landau (1983) concluded after studying 65 under developed countries that the consuming expenses of the government had a meaningful effect on decreasing the growth, and capital expenses of the government had a little but positive effect on economic growth. Using data from 20 African countries, Bairam (1990) showed that increasing the government expenses caused decreasing economic growth in 11 of them. Barro (1991) balanced Landau's data by omitting educational \& defensive expenses of the government to capture consuming expenses, and concluded that the proportion of government expenses to the total internal production has a negative effect on economic growth. Dar \& Amir (2002), Vedder and Gallaway (1998) found a nonlinear relation between the government size and economic growth, which can have a positive or negative effect on economic growth, depending on the government presence, there has been different results in the studies done in the country. A significant weakness of many of the previous studies on this topic (save for Ghali (1998), Loizides and Vamvoukas (2005) studies) was the failure to adjust for the co-integration result of the time series in the case of the trivariate framework that renders traditional statistical inference invalid. Thus, one of the aim of this study is to demonstrate the relationship between government size (measured as the share of total government expenditure in GDP) and economic growth and the principle aim of this paper is to empirically evaluate the causal link between the size of the public sector and real per capita GDP in Iran within the bivariate and trivariate frameworks. The combined analysis of bivariate and trivariate tests offers a rich menu of possible causal patterns. To this end, we employ cointegration analysis, error-correction modeling and multivariate causality test.

\section{Theoretical Framework}

In order to study the relationship between government size and economic growth in long run, Vector auto regressive pattern is used as follows:

$$
l G D P_{t}=\lambda_{0}+\sum_{i=1}^{n} \lambda_{1 i} l G D P_{t-i}+\sum_{i=1}^{n} \lambda_{2 i} l G S I Z E_{t-i}+u_{t}
$$


Where LGDP is the logarithm of real gross domestic product per capita and LGSIZE is the logarithm of public sector size which is measured as the ratio of real government expenditure to gross domestic product. In order to investigate the impact of another variable on the relationship between government size and economic growth, unemployment and oil revenue are decided to enter separately as the third variable and the model is changed as follows:

$$
\begin{gathered}
l G D P_{t}=\alpha_{0}+\sum_{i=1}^{n} \alpha_{1 i} l G D P_{t-i}+\sum_{i=1}^{n} \alpha_{2 i} l G S I Z E_{t-i}+\sum_{i=1}^{n} \alpha_{3 i} U N_{t-i}+e_{t}(2) \\
l G D P_{t}=c_{0}+\sum_{i=1}^{n} c_{1 i} l G D P_{t-i}+\sum_{i=1}^{n} c_{2 i} l G S I Z E_{t-i}+\sum_{i=1}^{n} c_{3 i} \operatorname{lOILR}_{t-i}+\varepsilon_{t}
\end{gathered}
$$

$\mathrm{UN}_{\mathrm{t}}$ is unemployment rate and $\mathrm{OILR}_{\mathrm{t}}$ is oil revenue.

After showing the relationship between government size and economic growth in long run, the short run relationship was studied by using the Error Correction Method. In the next step, this paper seeks to show the causal relationship in long and short run and also causal direction between government size and economic growth. The causal relation is evaluated once in bivariate and then with considering unemployment and oil revenue separately to investigate the effect of the third variable on the causal relationship between government size and economic growth.

To indicate causality in short run, the coefficient test is done on the following equations:

$$
\begin{aligned}
& \operatorname{DIGDP}_{\mathrm{t}=}=\mathrm{a}_{0}+\mathrm{a}_{1} \mathrm{E}_{\mathrm{t}-1}+\sum_{\mathrm{i}=1}^{\mathrm{n}} \mathrm{a}_{2 \mathrm{i}} \text { DIGDP }_{\mathrm{t}-\mathrm{i}}+\sum_{\mathrm{i}=1}^{n} \mathrm{a}_{3 \mathrm{i}} \text { DIGSIZE }_{\mathrm{t}-\mathrm{i}}+u_{\mathrm{t}} \\
& \operatorname{DlGSIZE}_{t}=\mathrm{b}_{0}+b_{1} \mathrm{C}_{\mathrm{t}-1}+\sum_{\mathrm{i}=1}^{n} b_{2 i} \operatorname{DlGDP}_{\mathrm{t}-\mathrm{i}}+\sum_{\mathrm{i}=1}^{\mathrm{n}} b_{3 \mathrm{i}} \operatorname{DIGSIZE}_{\mathrm{t}-\mathrm{i}}+\mathrm{e}_{\mathrm{t}}
\end{aligned}
$$

Then the presence of the causality relation is evaluated by entering the third variable using following equations:

$$
\begin{aligned}
& \operatorname{DIGDP}_{\mathrm{t}}=\alpha_{0}+\alpha_{1} \mathrm{E}_{\mathrm{t}-1}+\sum_{\mathrm{i}=1}^{\mathrm{n}} \alpha_{2 \mathrm{i}} \operatorname{DIGDP}_{\mathrm{t}-\mathrm{i}}+\sum_{\mathrm{i}=1}^{\mathrm{n}} \alpha_{3 \mathrm{i}} \operatorname{DIGSIZE}_{\mathrm{t}-\mathrm{i}}+\sum_{\mathrm{i}=1}^{\mathrm{n}} \alpha_{4 \mathrm{i}} \mathrm{DZ}_{\mathrm{t}-\mathrm{i}}+\mathrm{u}_{\mathrm{t}} \text { (6) } \\
& \operatorname{DIGSIZE}_{\mathrm{t}}=\beta_{0}+ \beta_{1} \mathrm{C}_{\mathrm{t}-1}+\sum_{\mathrm{i}=1}^{\mathrm{n}} \beta_{2 \mathrm{i}} \operatorname{DIGDP}_{\mathrm{t}-\mathrm{i}}+\sum_{\mathrm{i}=1}^{\mathrm{n}} \beta_{3 \mathrm{i}} \operatorname{DIGSIZE}_{\mathrm{t}-\mathrm{i}}+\sum_{\mathrm{i}=1}^{n} \beta_{4 \mathrm{i}} \mathrm{DZ}_{\mathrm{t}-\mathrm{i}} \\
&+\mathrm{e}_{\mathrm{t}}
\end{aligned}
$$

In which $\mathrm{Z}_{\mathrm{T}}$ is once the unemployment rate and once oil revenue.

\section{Results}

This section presents the empirical results for Iran. It starts by presenting the data. It then shows the results of testing for the long run and short run relationship and then bivariate and trivariate causality.

The Data: The data employed in this study are annual time series data (1971-2008). The main data source is the central bank of Islamic Republic of Iran dataset complemented with Statistical Yearbook of Iran's Statistics Center.

Unit Root Tests: The preliminary step of co-integration procedure is testing for the presence of a unit root in the series of interest. Thus, to test formally for the presence of a unit root for each variable in the model, Augmented Dickey-Fuller (ADF) test is considered. The test result indicates that all the variables are stationary in first differences, except the oil revenue. In Perron's view point (1989), in performing unit root tests, special care must be taken if it is suspected that structural change has occurred. Perron's structural change test has been done, due to revolution; war years in Iran during 1971-2007. As far as the structural 
change test was concerned, any of time series data did not have structural breaks. As a result, the integration degrees of economic growth, government size and unemployment rate were I (1). Table (1) shows the ADF test result, for the variables in levels and in first differences.

Table 1: The ADF test

\begin{tabular}{llc}
\hline Variable & Level & First differences \\
\hline LGDP & -1.16 & -4.43 \\
LGSIZE & -3.28 & -3.32 \\
UN & -2.46 & -6 \\
INF & -3.63 & - \\
\hline
\end{tabular}

Source: Authors' calculations.

Notes: In ADF test, we assume that the data have a constant and a linear trend.

The lags for ADF test were chosen based on SIC.

The critical values at the $5 \%$ significance level of (Hamilton, 1994) are (-2.93) and (-3.56) for the ADF test in the level and the first differences.

Long run and short run relationship: The link between economic growth and government size in bivariate and trivariate models is estimated by using these equations:

$$
\begin{gathered}
l G D P_{t}=\lambda_{0}+\sum_{i=1}^{n} \lambda_{1 \mathrm{i}} l G D P_{t-i}+\sum_{i=1}^{n} \lambda_{2 \mathrm{i}} l G S I Z E_{t-i}+\mathrm{u}_{\mathrm{t}} \\
l G D P_{t}=\alpha_{0}+\sum_{i=1}^{n} \alpha_{1 i} l G D P_{t-i}+\sum_{i=1}^{n} \alpha_{2 i} l G S I Z E_{t-i}+\sum_{i=1}^{n} \alpha_{3 i} U N_{t-i}+e_{t} \\
l G D P_{t}=a_{0}+\sum_{i=1}^{n} a_{1 i} l G D P_{t-i}+\sum_{i=1}^{n} a_{2 i} l G S I Z E_{t-i}+\sum_{i=1}^{n} a_{3 i} I N F_{t-i}+\varepsilon_{t}
\end{gathered}
$$

Having determined that the three variables are stationary in first differences and thus they have the same order of integration, we perform the Johansen cointegration test (1991) for bivariate equation and the first trivariate equation by considering the unemployment rate as the third variable. In the first stage, the order of lag length is obtained from unrestricted vector autoregressive (VAR) via Schwartz Bayesian Criteria and Akaike Information Criteria. Since we have a few observations, Schwartz Bayesian Criteria is used for the lag length. According to this criteria lag 2 and lag 1 are determined for bivariate and triavariate equation respectively. We applied the Johansen's trace and maximum eigenvalue ( $\lambda$ - max) tests to determine whether the variables in each system are cointegrated, and if so, how many cointegrating vectors would be identified from the system. Cheung and Lai (1993) suggest that the trace test shows more robustness to skewness and excess kurtosis in the residual rather than the maximum eigenvalue test It is also robust to departures from hetroskedasticity (Johansen, 1995). The Johansen test results are shown in Table 2 and 3.

Table 2: Bivariate Estimates of Johansen Cointegration Test

\begin{tabular}{llll}
\hline H0 & H1 & Trace & 5\% Critical value \\
\hline$r=0$ & $r \geq 1$ & 15.52 & 7.49 \\
$r \leq 1$ & $r \geq 2$ & 0.027 & 3.84 \\
\hline
\end{tabular}

Source: Authors' calculations

Table 3: Tivariate Estimates of Johansen Cointegration Test: The Case Unemployment

\begin{tabular}{llll}
\hline HO & H1 & Trace & 5\% Critical value \\
\hline$r=0$ & $r \geq 1$ & 26.69 & 23.8 \\
$r \leq 1$ & $r \geq 2$ & 15.64 & 8.49 \\
$r \leq 2$ & $r \geq 3$ & 1.65 & 3.84 \\
\hline
\end{tabular}

Source: Authors' calculations. 
At the 5\% significance level, the trace test indicates the presence of one cointegrating vectors for bivariate model and two vectors for trivariate one. Of the result of the cointegration indicates that there is a stable long-run relation among the variables in the system. Bahmani-Oskooee and Brooks' criterion is used for selecting optimal vector for trivriate model. The second vector is optimal. This method enables us to select a single-equation cointegration vector. The results are shown in Tables 4 and 5.

\section{Figure1: Cointegrating vectors in trivariate model: the case of unemployment}

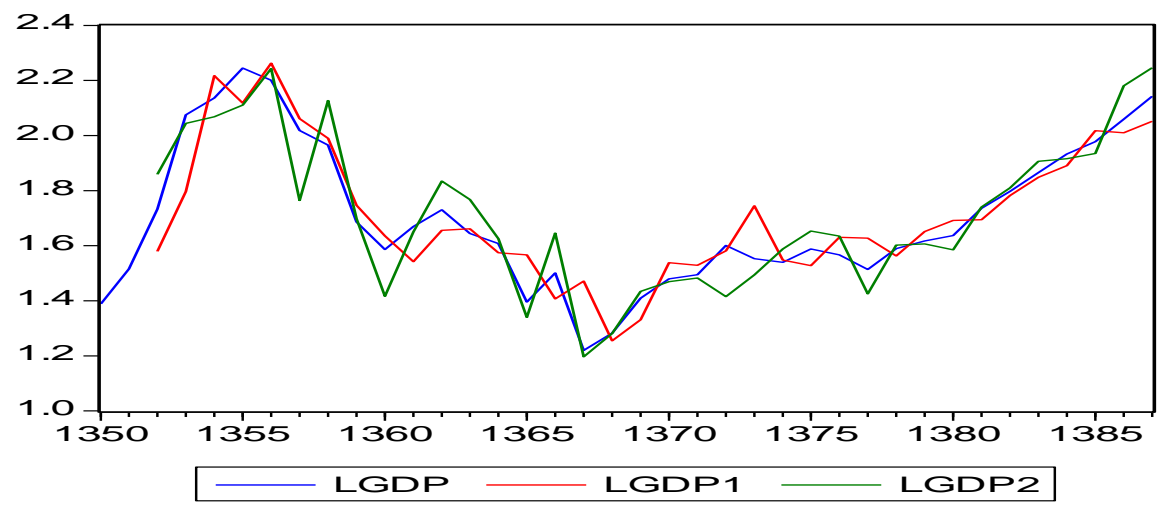

Table 4: Cointegration Vector for Bivariate Model

\section{Dependent variable}

Independent variable

LGDP

LGSIZE

1.53

Source: Authors' calculations.

Table 5: Cointegration Vectors for Trivariate Model: The Case of Unemployment

\begin{tabular}{ll}
\hline Dependent variable & \\
& LGDP \\
Independent variable & \\
LGSIZE & 1.191 \\
UN & 0.079 \\
\hline
\end{tabular}

Source: Authors' calculations.

The coefficients of government size on both the bivariate and trivariare models are negative. This finding supports the idea that government operations are often conducted inefficiently. For example, public investments undertaken by heavily subsidized and inefficient state owned enterprises in agriculture, manufacturing, energy banking and financial services, has more often reduced the possibilities for private investment and long-run economic growth? Moreover, many of the government fiscal and monetary policies tend to distort economic incentives and have a negative impact on the overall productivity of the system. The result for the trivariate model shows that introducing the unemployment rate as the third variable does not impact the negative long run relationship between government size and economic growth. Short run relationship is estimated by ECM ${ }^{1}$ model at the next step. The error correction terms serve as measures of disequilibrium, representing stochastic shocks in the dependent variables. They represent the proportion by which the long run disequilibrium in the dependent variables is corrected in each short term period. The ECM coefficients are expected to be negative and statistically significant. The results are shown as table 6 and 7 .

\footnotetext{
${ }^{1}$-Error Correction Model
} 
Table 6: Bivariate Estimates of ECM (model 1)

\begin{tabular}{lcl}
\hline Dependent variables & coefficient & t statistic \\
\hline Intercept & -0.01 & 0.56 \\
$\Delta$ LGDP(-1) & 0.253 & 2.56 \\
$\Delta$ LGDP(-2) & 0.177 & 1.05 \\
$\Delta$ LGSIZE $(-1)$ & 0.516 & 2.36 \\
$\Delta$ LGSIZE $(-2)$ & 0.127 & 0.58 \\
ECM $(-1)$ & -0.145 & -2.63 \\
$\overline{\mathrm{R}}^{2}$ & 0.54 &
\end{tabular}

Source: Authors' calculations.

Table 7: Ttrivariate Estimates of ECM (model 2); The Case of Unemployment

\begin{tabular}{lll}
\hline Dependent variables & coefficient & t statistic \\
\hline Intercept & 0.16 & 0.86 \\
$\Delta$ LGDP $(-1)$ & 0.373 & 2.32 \\
$\Delta$ LGSIZE $(-1)$ & 0.539 & 2.94 \\
$\Delta \mathrm{UN}(-1)$ & 0.01 & 0.76 \\
ECM $(-1)$ & -0.24 & -2.06 \\
$\overline{\mathrm{R}}^{2}$ & 0.54 & \\
\hline
\end{tabular}

Source: Authors' calculations.

It indicates that about 10 percent (in bivariate model) and 20 percent (in trivariate model) of any disequilibrium between actual and equilibrium of GDP, in any period, is made up during the current period.

ARDL2 ${ }^{2}$ Test: It was shown in the unit root test that the oil revenue is stationary in level. According to this, ARDL test is used for long run relationship. The results are shown as table 8.

Table 8: Trivariate Estimates of ARDL: The Case of Oil Income

\begin{tabular}{lc}
\hline Regressor & Coefficient \\
\hline Intercept & 0.15 \\
LGDP(-1) & 0.80 \\
LGSIZE & -0.21 \\
LOILR & 0.16 \\
LOILR(-1) & -0.16 \\
LOILR(-2) & -0.08 \\
LOILR(-3) & -0.07 \\
& \\
$\overline{\mathrm{R}}^{2}=0.93$ & $\mathrm{dw}=1.9$ \\
\hline
\end{tabular}

Source: Authors' calculations.

The long run relationship is shown as follows: ${ }^{3}$

LGDP $=7 / 84-3 / 73$ LGSIZE -0.046 LOILR

(2.06) (0.027)

It indicates that considering the oil revenue as the third variable did not change the negative relationship between economic growth and government size. By considering the confirmation of the long run relation, ECM test is used for short run relationship. The results are shown as table 9.

\footnotetext{
2 -Auto Regressive Distributed Lag

3 - This negative relationship between growth and oil revenue, does not mean that oil revenue detrimental to growth. It simply means that over the period examined, oil revenue has been on average countercyclical, i.e. That average supply shocks(e.g. increases in oil prices) have dominated aggregate demand shocks( e.g. fiscal policies).
} 
Table 9: Ttrivariate Estimates of ECM (model 3); The Case of oil revenue

\begin{tabular}{lll}
\hline Dependent variables & coefficient & t statistic \\
\hline Intercept & -0.44 & -2.8 \\
$\Delta$ LGSIZE & -0.21 & -1.9 \\
$\Delta$ LOILR & 0.16 & 4.9 \\
$\Delta$ LOILR(-1) & -0.01 & -1.2 \\
$\Delta$ LOILR(-2) & 0.07 & 2.09 \\
ECM(-1) & -0.1 & -1.67 \\
$\overline{\mathrm{R}}^{2}$ & 0.7 &
\end{tabular}

Source: Authors' calculations.

The Causality: The main purpose of this study is to demonstrate the causal pattern between economic growth and government size in bivariate and trivariate framework. Wald coefficient test is used to show that causality. The coefficients of equations (1), (2) and (3), show the long run bivariate and trivariate causality. And Within the ECM formulation of (4), (5) and (6), government size does not cause economic growth if all $\mathrm{a}_{3 \mathrm{i}}=0$ and $\mathrm{a}_{1}=0$. Equivalently, economic growth does not cause government size if all $\mathrm{b}_{2 \mathrm{i}}=0$ and $\mathrm{b}_{1}=0$. However, it is possible that the causal link between economic growth and government size estimated from the bivariate equations could have been caused by a third variable. For this reason equation (6) is used for short run trivarite causality test. Wald test results are shown in Tables 10-15.

Table 10: Wald test result for bivariate causality in long run

\begin{tabular}{lll}
\hline $\mathbf{H}_{\mathbf{0}}$ & Chi-Square & Prob \\
\hline Government size does not cause economic growth & 8.95 & 0.011 \\
Economic growth does not cause government size & 2.98 & 0.225 \\
\hline
\end{tabular}

Source: Authors' calculations.

Table 11: Wald test result for bivariate causality in short run

\begin{tabular}{lll}
\hline $\mathbf{H}_{\mathbf{0}}$ & Chi-Square & Prob \\
\hline Government size does not cause economic growth & 10.30 & 0.016 \\
Economic growth does not cause government size & 4.62 & 0.202 \\
\hline
\end{tabular}

Source: Authors' calculations.

Table 12: Wald test result for trivariate causality in long run (the case of unemployment)

\begin{tabular}{lll}
\hline $\mathbf{H}_{\mathbf{0}}$ & Chi-Square & Prob \\
\hline Government size does not cause economic growth & 2.12 & 0.145 \\
Economic growth does not cause government size & 1.18 & 0.277 \\
\hline
\end{tabular}

Source: Authors' calculations.

Table 13: Wald test result for trivariate causality in short run (the case of unemployment)

\begin{tabular}{lll}
\hline $\mathbf{H}_{\mathbf{0}}$ & Chi-Square & Prob \\
\hline Government size does not cause economic growth & 12.05 & 0.007 \\
Economic growth does not cause government size & 1.40 & 0.706 \\
\hline
\end{tabular}

Source: Authors' calculations.

Table 14: Wald test result for trivariate causality in long run (the case of oil revenue)

\begin{tabular}{lll}
\hline $\mathbf{H}_{\mathbf{0}}$ & Chi-Square & Prob \\
\hline Government size does not cause economic growth & 4.39 & 0.036 \\
Economic growth does not cause government size & 12.21 & 0.002 \\
\hline
\end{tabular}

Source: Authors' calculations.

Table 15: Wald test result for trivariate causality in short run (the case of oil revenue)

\begin{tabular}{lll}
\hline $\mathbf{H}_{\mathbf{0}}$ & Chi-Square & Prob \\
\hline Government size does not cause economic growth & 24.17 & 0.000 \\
Economic growth does not cause government size & 7.05 & 0.029 \\
\hline
\end{tabular}

Source: Authors' calculations. 
The results show that within the bivariate system, government size causes economic growth in the long run and short run but not the other way round. These results are consistent with the Keynesian notion suggesting that the causal linkage flows from $\triangle$ GSIZE to $\triangle$ GDP both in the long run and the short run. By including the unemployment rate as the third variable, there will be no causality in the long run, but we still have one- waycausality from government size to economic growth in the short run. When oil revenue is introduced into the system, there will be two- way-causality between public sector size and economic growth in the long run and the short run. It shows that oil revenue explains the causation from economic growth to government size. This finding validates Wagner,s Law ${ }^{4}$, because real output seems to be an important determinant of long and short-run government size growth.

\section{Conclusion}

Utilizing annual data drawn from Iran, this paper has examined the relationship between government size and economic growth in both bivariate and trivariate system, based on cointegration analysis, ECM strategy and causality test. On the basis of our empirical results, the following broad conclusions emerge. First, the relationship between government size and economic growth is negative. This is borne out by the bivariate as well as the trivariate analysis. Second, there is a one-way causality pattern between government size and economic growth, and government size causes growth in GDP either in the short or long run. The analysis generally rejects the hypothesis that public expansion has hampered economic growth in Iran. Third, when unemployment rate is introduced as the third variables into the system, there will be no causality relationship in the long run. Although in the short run government size is still the cause of economic growth. Considering oil revenue as the third variable results in a two-way causality relationship between the government size and the economic growth. Finally, we believe that while other potential variables, like real interest rate or public debt over GNP, remain unexplored, the present study indicates the likely dimensionality of a macro model that would explain the behavioral relationship between economic growth and the size of the public sector.

\section{References}

Bairam, E. (1990). Government Size and Economic Growth: The African Experience, 1960-85.Applied Economics, 22, 1427-35.

Barro, R. J. (1991). Economic Growth in a Cross Section of Countries. The Quarterly Journal of Economics, 106(2), 407-443.

Cheung, Y. \& Lai, K. (1993). Finite-Sample Sizes of Johansen's Likelihood Ratio Tests for Cointegration. Oxford Bulletin of Economics and statistics, 55, 313-328.

Dar, E. \& Amir, k. (2002). Government Size, Factor Accumulation and Economic Growth: Evidence from OECD Countries. Journal of Policy Modeling, 24, 679-692.

Ghali, K. H. (1998). Government Size and Economics Growth; Evidence from a Multivariate Cointegration Analysis. Applied Economic, 31, 975-987.

Johansen, S. (1991). Estimation and Hypothesis Testing of Cointegration Vectors in Gaussian Vector Autoregressive Models. Econometrica, 59, 1551-80.

Johansen, S. (1995). Likelihood-Based Inference in Cointegrated Vector Autoregressive Models. New York Oxford University Press.

Kolluri B. (2000).Government Expenditure and Economic Growth: Evidence from G7 Countries. Applied Economics, 32, 1059-1068.

Landau, D. (1983). Government and Economic Growth in The Less Developed Countries: An Empirical Study for 1960-1980.The University of Chicago Press, 35(1), 35-75.

Loizides, W. \& Vamvoukas, Z. (2005). Government Expenditure and Economic Growth: Evidence from Trivariate Causality Testing. Journal of Applied Economics, 1, 125-152.

Perron, P. (1989). The great crash, the oil price shock, and the unit root hypothesis. Econometrica, 99, 13611401.

Ram, R. (1986). Government Size and Economics Growth: A New Framework and Some Evidence from CrossSection and Time- Series Data. American Economic Review, 79, 191- 203.

\footnotetext{
4 - The "Law of increasing expansion of public and particularly state activities" (Wagner, 1893)- is one of the earliest attempts that emphasize economic growth as the fundamental determinant of public sector growth.
} 
Ram, R. (1986). Government Size and Economics Growth: A New Framework and Some Evidence from CrossSection and Time- Series Data: Reply. American Economic Review, 79, 281- 284.

Romer, D. (2001). Advanced Macroeconomics, McGraw-Hill

Wagner, A. (1893). Grundlegung der Politischen Okonomie, $3^{\text {rd }}$ ed., Leipzig, C.F. Winter

Vedder, T. \& Gallaway, Y. (1998). Government Size and Economic Growth, Paper Prepared for The Joint Economic Committee of The US Congress, 1-15. 